\title{
複断面河道における洪水流の伝播機構 PROPAGATION MECHANISM OF FLOOD FLOW IN COMPOUND CHANNELS
}

\author{
福岡捷二 ${ }^{1}$ 口佐藤宏明 2 口出口桂輔 3
}

Shoji FUKUOKA, Hiroaki SATO and Keisuke DEGUCHI

\begin{abstract}
${ }^{1}$ フェロー会員 工博 Ph.D 中央大学研究開発機構教授（广 112-8551 東京都文京区春日 1-13-27)
${ }^{2}$ 正会員（財)河川情報センター 研究第一部長 (₹ 102-8474 東京都千代田区敖町 1-3 ニッセイ半蔵門ビル)

3 学生会員 中央大学大学院 理工学研究科 土大工学専攻 博士課程前期（广 112-8551 東京都文京区春日 1-13-27)
\end{abstract}

\begin{abstract}
It is very important for the river management to grasp the hydraulic characteristics of flood flow in compound channels. The propagation speed of flood flow in compound channels has not yet been known, although that in simple cross-section channels was showed by Kleitz-Seddon. This study aims to clarify the propagation mechanism of flood flow and compare propagation speed from laboratory experiments with those of the theoretical expression derived for compound channels. As a result, theoretical formula provides a good expression for propagation speed of compound channels. Furthermore, we explain the effect of change in the channel cross-section on the flood propagation speed in rivers. Finally, we investigate propagation characteristics of various flood flows in the Tone River and Edo River.
\end{abstract}

Key Words: propagation mechanism, flood flow, compound channel, channel cross-section, theoretical analysis

\section{1 . 序論}

洪水流が河道を流下していく際の樣々な水理特性 の変化について, より深い理解を得ることは, 河川 管理上重要な意義を持つ. 我が国の大河川の多くが 有する複断面河道について, これまで樣々な研究が 行われ，多くの知見が得られてきた $\left.{ }^{1)} 2\right)$.

洪水伝播速度について, 古くは Kleitz-Seddon に よって十分幅の広い単断面流路では波速が流速の 5/3 倍となることが示されている ${ }^{1)}$.しかし, 複雑な 断面形状を有する実河道においては,Kleitz-Seddon 式は光の特徵をうまく捉えられないことが既に示さ れており, 複断面河道における洪水流の伝播を含む 水理現象を数值解析的に検討されるのが一般的とな っている2). しかし，Kleitz-Seddon と同樣に解析 的に複断面河道の洪水伝播について検討することは， 現象を物理的視点に基づいて考察する上で重要であ り, また, 治水計画で想定される河道改修や樹木管 理, 水防活動, 避難の際の情報など重要な判断材料 を与えることになる．

本研究は, 河道が複断面形状によることの特性を 考慮した洪水流の伝播速度について, 理論式の導出
と理論式と広島大学における洪水流室内実験から得 られたデータ ${ }^{4)}$ との比較検討を行う. 加えて，利根 川，江戶川における昭和 57 年, 平成 10 年洪水の実 測水位データから洪水の伝播特性を調へ，実河川に おける理論式の適用性の検討を行う. 最後に本研究 の持つ意義を述べる .

2 . 複断面河道における洪水流の伝播速度

図-1のように断面分割法を用いて左右対称な複断

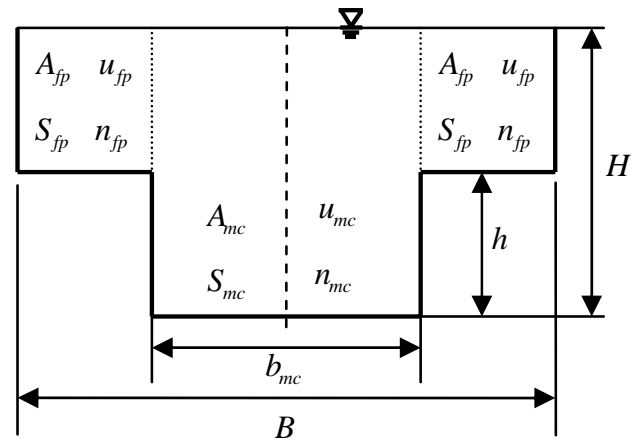

記号の説明 $(A$ :河積， $u$ : 断面平均流速， $B$ : 全幅， $b_{m c}$ : 低水路幅, $n$ :粗度係数, $S$ : 潤辺, $h$ : 低水路深 さ $m c \stackrel{H}{H}$ : 低水路底からの水深, 添字 $f p$ は高水敷を, $m c$ は低水路を表す.)

图-1 複断面河道の横断面形 
面直線河道を考え, 連続式と運動方程式から, 以下 の式(1)，(2)のように波形を変えずに伝播する最大 水深の伝播速度 $d Q / d A$ を算出した．なお，低水路 と高水敷の分割面に作用するせん断力 $\mathrm{T}$ を式(5)で 表現し, 低水路, 高水敷光れ光れの力のつり合い条件 から式( 3)，(4) を連立して解くことで低水路, 高水 敷の流速 $u_{m c}, u_{f p}$ を求め,式(6)より任意の水位に対 する流量 $Q$, 式( 2) より伝播速度 $C$ を求めている. $N_{c}$ は合成粗度係数, $I_{e}$ はエネルギー勾配，vは断 面平均流速， $R_{c}$ (合成径深を示す ${ }^{1) 2) . ~}$

$$
\begin{gathered}
\left(\frac{\partial}{\partial t}+\frac{d Q}{d A} \frac{\partial}{\partial x}\right) A=0 \\
C=\frac{d Q}{d A}=\left(\frac{5}{3} \frac{b_{m c}}{B}-\frac{4}{3} \frac{h}{H} \frac{R_{m c}}{B}\right) \frac{1}{N_{c}} R_{m c}^{2 / 3} I_{e}^{1 / 2} \\
+2\left\{\frac{5}{3} \frac{\left.1-b_{m c} / B\right)(1-h / H)}{2}-\frac{2}{3}\left(1-\frac{h}{H}\right) \frac{R_{f p}}{B}\right\} \frac{1}{N_{c}} R_{f p}^{2 / 3} I_{e}^{1 / 2} \\
\frac{\rho g n_{m}^{2} S_{m c}}{R_{m c}^{1 / 3}} u_{m c}^{2}+\tau \cdot(H-h)=\rho g A_{m c} I_{e} \\
\frac{\rho g n_{f p}^{2} S_{f p}}{R_{f p}^{1 / 3}} u_{f p}^{2}-\tau \cdot(H-h)=\rho g A_{f p} I_{e} \\
\tau=\rho \cdot f \cdot\left(u_{m c}-u_{f p}\right)^{2} \\
Q=A_{m c} u_{m c}+2 A_{f p} u_{f p} \\
R_{c}=\left\{\frac{A_{m c}+2 A_{f p}}{Q} \cdot R_{c}^{2 / 3} \cdot I_{e}^{1 / 2}\right. \\
A_{m c}\left(A_{m c} / S_{m c}\right)^{2 / 3}+2 A_{f p}\left(A_{f p} / S_{f p}\right)^{2 / 3} \\
A_{m c}+2 A_{f p} \\
v=\frac{1}{N_{c}} R_{c}^{2 / 3} I_{e}^{1 / 2}
\end{gathered}
$$

ここで， $\rho$ は水の密度である $f$ は低水路と高水敷 との境界での混合の激しさを表す混合係数で, 本研 究では既往の研究 ${ }^{2)}{ }^{3)}$ から境界混合係数を $f=0.17$ とした．断面分割法を用いることで，伝播速度に対 する樣々な複断面形状や，低水路・高水敷の粗度の 影響を取り込めること, 高水敷の遅い流れと低水路 の速い流れが混合することの影響を考慮することが 可能である . 式 (2) は直線河道で洪水が形を変えず に伝播するときの式であり，堤防や低水路の線形， 樹木群の違いについては直接的には考慮していない． しかし, 蛇行や樹木群等の洪水流の伝播速度に及ぼ す影響は式(2)の水深と合成粗度係数等に反映して
表- 1 実験条件 4$)$

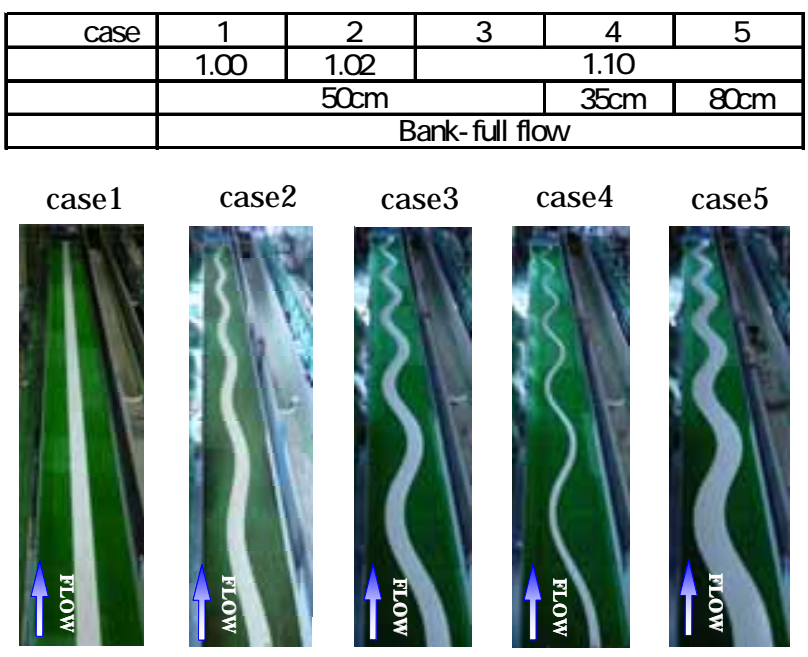

図- 2 実験水路 4 )

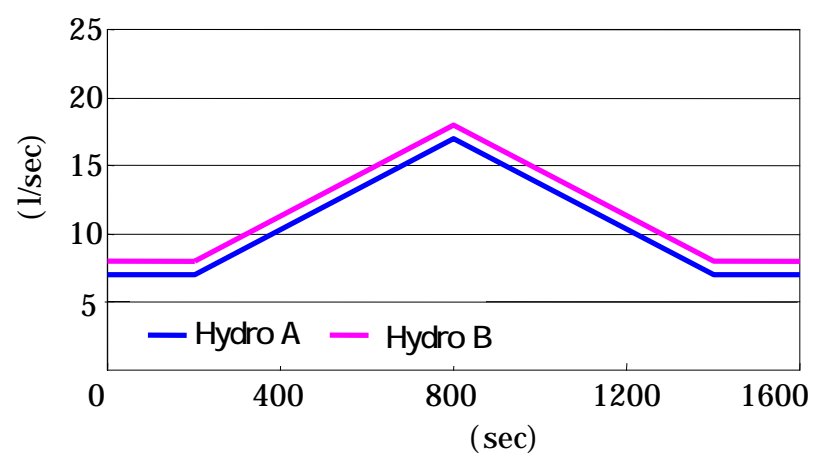

図- 3 設定流量ハイドログラフ ${ }^{4}$

いることから，実測の最大水深と合成粗度係数等を 用いることにより，間接的にこれらの影響を考慮し た伝播速度を求めることが可能である．

\section{3 . 実験水路における洪水流の伝播速度の検討 \\ （1）検討方法}

洪水流の伝播速度の理論值と実験值の比較と光の 考察を行う.検討に用いたデータは, 福岡ら ${ }^{4)}$ が広 島大学で行った複断面水路 ( 全長 $21.5 \mathrm{~m}$ ) を用いた洪 水実験データを使用した。実験条件と実験水路，設

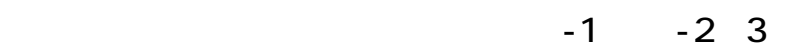
示す.実験は各 case で蛇行度と低水路幅を変化させ て全部で5case行っている.case1〜3 を比較するこ とで蛇行度の違いによる影響を, case3〜 5 を比較す ることで低水路幅の違いによる影響を検討する．

実験の初期状態として低水路満杯状態から洪水を 流下させるため, case1〜4では HydoroA を, 低水 路幅の広い case5 では流量の多い Hydoro B を用い ている. case4 では低水路が狭いことから，初期状 態で高水敷が冠水した状態となっている．測定項目 として, 水位は低水路中央で縦断的に 9 点, 横断的 には高水敷上で 9 点，低水路内で 5 点測定している . 
表- 2 洪水流の伝播速度の実験值と理論値の比較

単位 : $\mathrm{cm} / \mathrm{s}$

\begin{tabular}{|r|r|r|r|r|r|r|r|r|r|r|}
\hline & \multicolumn{2}{|c|}{ case1 } & \multicolumn{2}{c|}{ case2 } & \multicolumn{2}{c|}{ case3 } & \multicolumn{2}{c|}{ case4 } & \multicolumn{2}{c|}{ case5 } \\
\hline & No.1 & \multicolumn{1}{|c|}{ No.2 } & \multicolumn{1}{|c|}{ No.1 } & \multicolumn{1}{|c|}{ No.2 } & No.1 & No.2 & No.1 & No.2 & No .1 & No.2 \\
\hline \hline 実験値 & 22.3 & 15.9 & 19.0 & 21.8 & 26.5 & 23.1 & 25.6 & 20.5 & 22.1 & 32.0 \\
\hline 理論値 混合なし) & 20.5 & 20.3 & 22.1 & 22.0 & 24.6 & 24.2 & 24.9 & 22.6 & 26.2 & 26.9 \\
\hline 理論值 焜合あり) & 19.9 & 20.0 & 21.6 & 21.5 & 24.2 & 23.8 & 22.7 & 20.6 & 25.6 & 26.3 \\
\hline
\end{tabular}
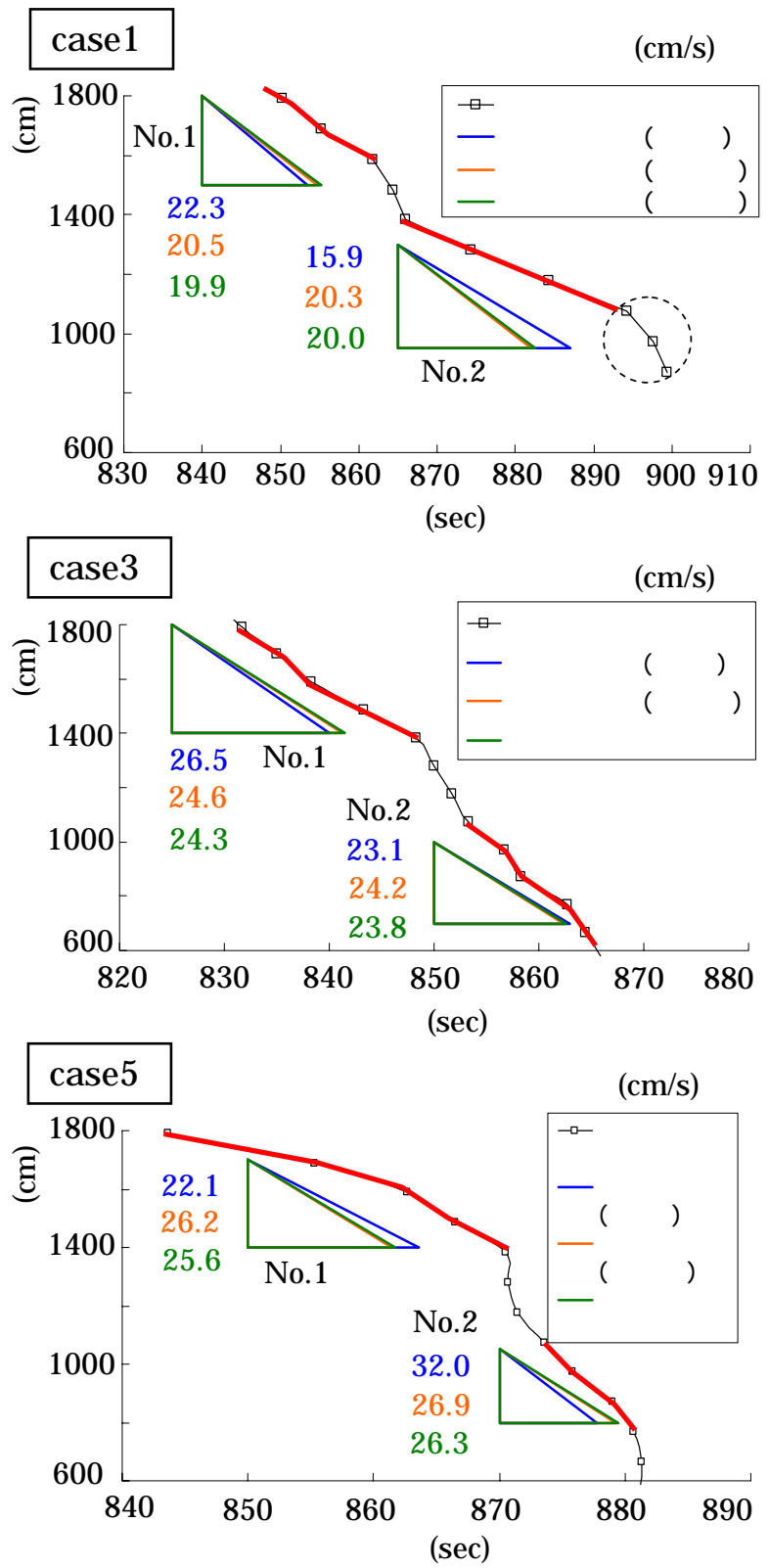

图-4 最大水深の伝播の樣子と伝播速度の 理論值と実験值の比較

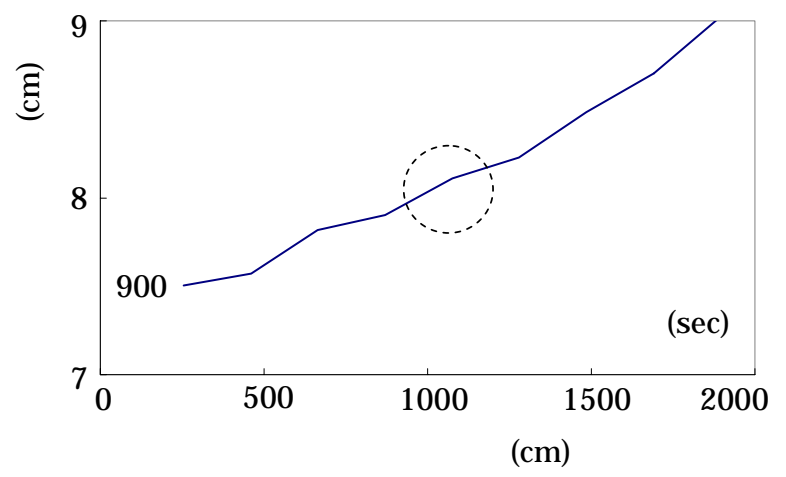

図- 5 実験水路水面形( casel)

表-3 蛇行度の違いによる影響

\begin{tabular}{|l|r|r|r|}
\hline & case1 & case2 & \multicolumn{1}{l|}{ case3 } \\
\hline 蛇行度 & 1.00 & 1.02 & 1.10 \\
\hline 最大水深 $(\mathrm{cm})$ & 7.16 & 7.44 & 7.69 \\
\hline 平均伝播速度 琠験 $) \mathrm{cm} / \mathrm{s}$ & 19.1 & 20.4 & 24.8 \\
\hline 平均伝播速度 理論 $) \mathrm{cm} / \mathrm{s}$ & 20.0 & 21.6 & 24.0 \\
\hline ピーク流量 $(\mathrm{I} / \mathrm{s})$ & \multicolumn{3}{|c|}{ HydroA } \\
\hline
\end{tabular}

表-4 低水路幅の違いによる影響

\begin{tabular}{|c|c|c|c|}
\hline & case3 & case4 & case5 \\
\hline 低水路幅(cm) & 50 & 35 & 80 \\
\hline 最大水深 $(\mathrm{cm})$ & 7.98 & 9.06 & 7.64 \\
\hline 平均伝播速度 実験) $\mathrm{cm} / \mathrm{s}$ & 24.8 & 23.1 & 27.1 \\
\hline 平均伝播速度 理論 $) \mathrm{cm} / \mathrm{s}$ & 24.0 & 21.7 & 26.0 \\
\hline ピーク流量 $(\mathrm{s})$ & \multicolumn{2}{|c|}{ HydroA } & HydroB \\
\hline
\end{tabular}

流速は水位の測定点と同じ位置で鉛直方向に低水路 内で 4 点，高水敷上で 2 点測定されている(河床よ り $1 \mathrm{~cm}$ を始点として $2 \mathrm{~cm}$ 間隔).流量は上流端の断 面では電磁流量計で, 弚れより下流の断面の流量に ついては電磁流量計の流量と各断面で計測した水位 から貯留量を求め，算出している．

洪水流の伝播速度は, 隣り合う 2 断面の水位八イ ドログラフから，ピーク水位の発生時刻の差と断面 間の距離から算出している.

洪水流の伝播速度の理論值は式( 2) を用い，実験 中に観測した最大水深を与えて求めている. 境界に おける混合の影響は，式( 5) で考慮し $f=0.17$ を与え て算出したものを「混合あり」, $f=0$ として算出し たものを混合なしロとしている．

\section{（2）実験値と理論值の伝播速度の比較，検討}

図-4に case1 , 3，5 における実験結果を一例とし て示す.また，図 5 には casel におけるピーク水位 時間の水位縦断形を示す.図-4の casel 中に丸破線 で示した箇所は,水面形に変化が生じている箇所で, 図- 5 中に示した丸破線の水面形の変化点と対応し ている.水面形の変化は，準等流を作るために下流 端の堰を調節したことによる影響が伝播し，水深が 変化しているためである.図-4は赤い太線区間につ いて伝播速度の実験値とエネルギー勾配を用い求め た理論値を傾きで示したものである.図-4，表-2の No.1，No.2 は水面形の区間に対応しており，算出 位置を表している . 洪水伝播速度について単純化さ れた理論にもかかわらず，実験值を比較的良く表現 
できている.表- 2 に示すように case2 と case4 につ いても同樣にほほ説明できている .

洪水流の伝播に及ぼす蛇行度の影響は, casel〜3 の比較から検討する. 表- 3,4 の平均伝播速度は， 表- 2 に示した各 caseの No.1 ,No.2 の理論值 (混合 あり) の平均值である . 表- 3の case1〜3 は , 同じ 低水路幅, 高水敷幅に対し, 最大水深は蛇行度が大 きくなるほど増大している .これは蛇行度の増大に つれて, 蛇行帯幅が大きくなり, 低水路流れと高水 敷流れの混合による流れの抵抗が大きくなるためで ある. 蛇行度が大きくなるほど伝播速度の実験値も 理論値も大きくなっている. 理論式は, 蛇行を直接 的には考慮していないが, 前述したように蛇行の影 響は水深等に反映して評価されていることによる．

次に, 蛇行度は同一であるが, 低水路幅の違いに よる影響を case3〜 5 の結果をもとに検討する．表 -4から，低水路幅が大きくなるほど最大水深は小さ くなるが，伝播速度は実験值も理論值も大きくなっ ている . 実験時の流況を見ると，低水路幅が広がる につれて流れの主流線の曲率が小さくなり, 流れが 低水路に集中して直線的な単断面的な流れに近くな る.このように, 蛇行度が同じであっても低水路幅 の違いによって流れ方は変化することから, 全幅が 一定である水路においては, 低水路幅が伝播速度を 決める支配的な要因となっている .

\section{4 . 水路横断面形状を変化させた場合の洪水伝 播速度の変化}

図- 6 に水路幅 $B$ と水面高さ, 河床高を固定 $(H$ ： 一定) し, 断面内の形状 $\left(b_{m c}, h\right)$ を変化させた時 の伝播速度 $C$ を断面平均流速 $て て ゙$ 除した無次元量 $C / v$ の計算結果を示す. 計算には実験水路の条件 $\left(n, I_{b}\right)$ を与え, 式(2)と式(9)を用いている.この とき, 各断面形を流下する流量については, 与えた 断面形, 水位に相当する流量となっている . 横軸に $b_{m c} / B$, 縦軸に $h / H$ を取り，C/vの值は色の濃淡 で示している . 図中には $b_{m c} / B, h / H$ の関係から 想定される横断面形状のイメージを 9 等分して表現 した .この図から,$b_{m c} / B$ が大きく $h / H$ が小さい 図中右下の断面形をとるほど，C/vは大きくなり， 逆に左上のような低水路が狭く深い河道ほど $C / v$ が小さくなることが分かる .ここで, 実河川の断面 平均流速 $v$ にいては樹木群等があるときにも式 ( 9) が適用可能であるかを検討する必要がある . ま た, この計算結果は, 水路実験等によって具体的に 確認することも必要であるが, 河道の横断面形状の

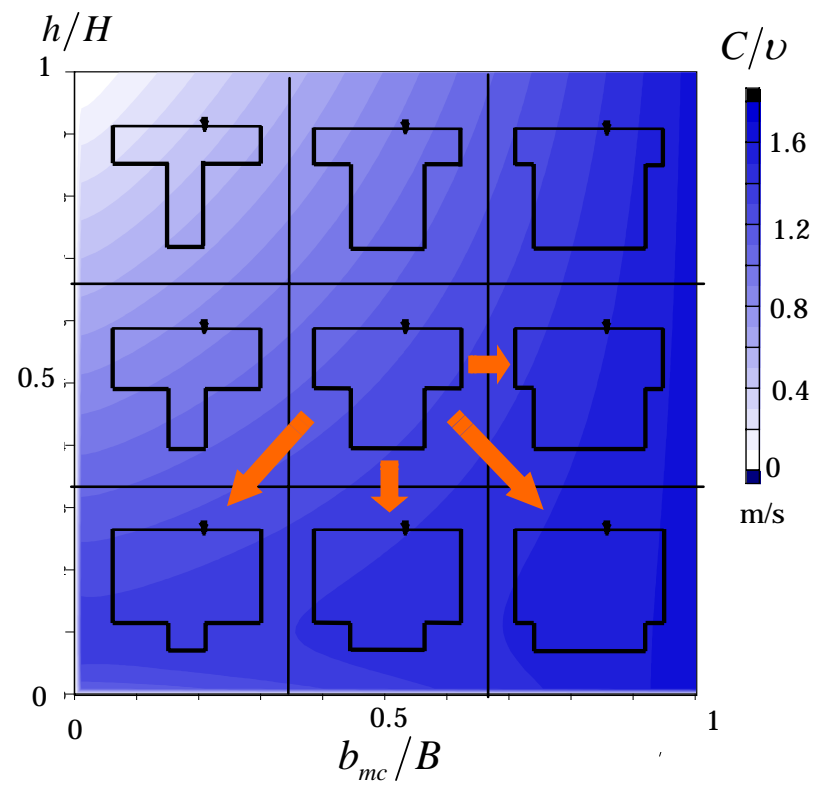

図- 6 横断面形状を変化させた場合の 伝播速度- 断面平均流速比の变化

作り方が洪水流の伝播速度，すなわち洪水継続時間 に影響することを示しており，河道改修時にはこの 点を十分考慮しなければならない .

\section{5 . 利根川，江戶川における洪水流の伝播特性}

\section{（1）利根川，江戶川の河道特性}

図- 7 に，利根川，江戶川の検討対象区間を示す． 利根川は栗橋〜芽吹橋までの江戶川への分派区間を 含む約 $26 \mathrm{~km}$, 江戶川は西関宿〜野田までの約 $20 \mathrm{~km}$ を対象としている．図-8に栗橋，芽吹橋，西関宿， 野田地点の河道横断面形状及び昭和 57 年, 平成 10 年の洪水の水位ハイドログラフを示す . 利根川, 栗 橋地点における観測ピーク流量は, 昭和 57 年が $11,600 \mathrm{~m}^{3} / \mathrm{s}$,平成 10 年が $10,400 \mathrm{~m}^{3} / \mathrm{s}$ で, 江戶川， 野田地点における観測ピーク流量は, 昭和 57 年が $2,900 \mathrm{~m}^{3} / \mathrm{s}$ ，平成 10 年が $2,500 \mathrm{~m}^{3} / \mathrm{s}$ である.これ より，2つの洪水は, ほぼ同規模の洪水でありピー ク水位もほぼ同じと考えてよい．

次に, 昭和 57 年洪水時から平成 10 年洪水時の間 の河道の変化を示す . 利根川では, 図-8の栗橋, 芽 吹橋の横断面形状の経年的な変化から見てとれるよ うに，昭和 57 年から $\mathrm{H} 10$ 年の間に対象としたほぼ 全区間にわたって低水路河床高が低下し, 河積が増 大している . また, 昭和 57 年から平成 10 年までの 間の航空写真や地被情報等から, 河道の平面形の大 きな変化は見られなかった。しかし, 河道内, 特に 分派点付近で樹木群か繁茂している。

江戶川では, 図-8の西関宿, 野田の横断面形状か ら若干河床の低下は見られるが, 対象とした区間に 


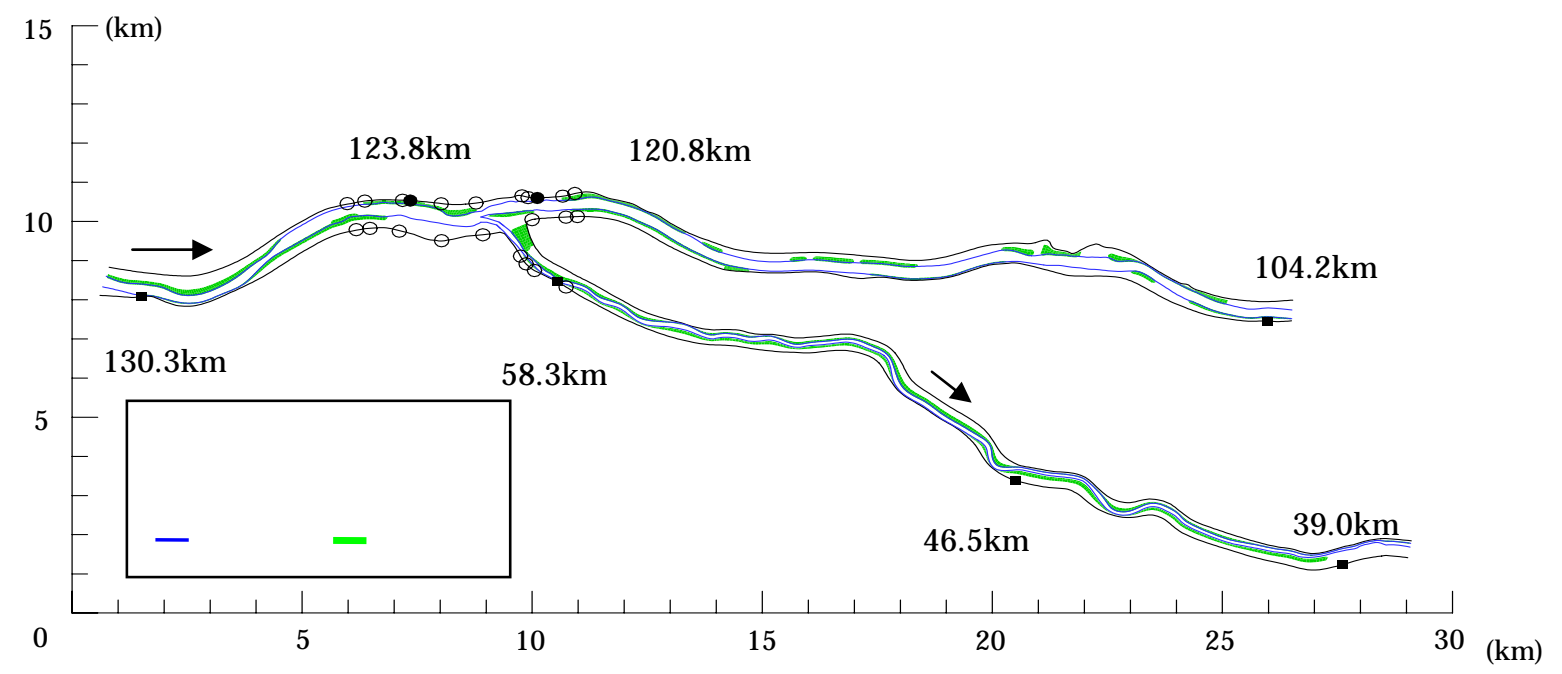

図-7 利根川・江戶川における対象区間の平面形および地被状況
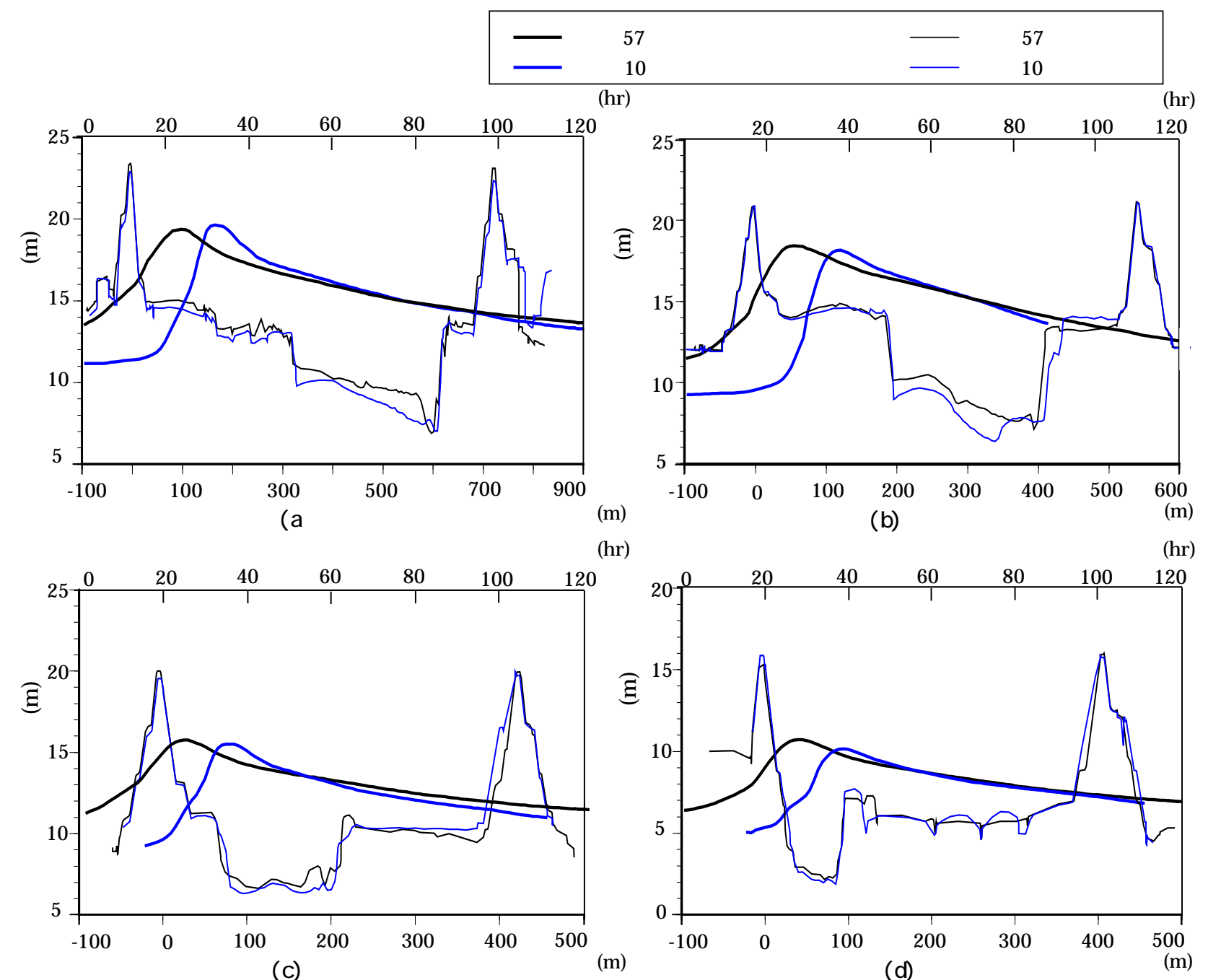

図-8 基準点の横断面形状および水位ハイドログラフ

おいては,乥れほど大きな河積の変化は見られない． しかし, 利根川と同樣に航空写真や地被情報等から 樹木群の繁茂を確認することができる．このように 昭和 57 年から平成 10 年の間に利根川, 江戶川とも に樹木群によって河積が減じ，洪水流の伝播速度に 影響していることが考えられる .
（2）計算と実測の伝播速度の比較検討

現地の洪水水位ハイドログラフ観測値には，洪水 の規模, 河川の縦横断面形の変化, 樹木群の抵抗等 が積分された形で表れている.一方，検討に用いた 断面形状は，500m 間隔に測量された定期横断形を 各断面について矩形近似したものを用いた . 水深は 
表- 5 利根川分派点前後の平均的な水面勾配と計算伝播速度及び実測伝播速度

\begin{tabular}{|c|r|r|r|r||r|}
\hline & \multicolumn{2}{|c|}{ 栗橋～分派点 } & \multicolumn{2}{|c||}{ 分派点〜芽吹橋 } & \multicolumn{1}{|c|}{ 栗橋〜芽吹橋 } \\
\cline { 2 - 6 } & \multicolumn{1}{|c|}{ 水面勾配 } & 伝播速度 $(\mathrm{m} / \mathrm{s})$ & 水面勾配 & 伝播速度 $(\mathrm{m} / \mathrm{s})$ & 実測伝播速度 $(\mathrm{m} / \mathrm{s})$ \\
\hline 昭和57年 & $1 / 4800 \sim 1 / 5300$ & $1.6 \sim 2.3$ & $1 / 4000 \sim 1 / 5900$ & $1.6 \sim 2.1$ & 2.42 \\
\hline 平成10年 & $1 / 4500 \sim 1 / 5600$ & $1.4 \sim 2.2$ & $1 / 4200 \sim 1 / 6000$ & $1.8 \sim 2.5$ & 1.21 \\
\hline
\end{tabular}

表- 6 江戶川 $47 \mathrm{~km}$ 地点前後の平均的な水面勾配と計算伝播速度及び実測伝播速度

\begin{tabular}{|c|c|c|c|c|c|}
\hline & \multicolumn{2}{|c|}{ 47km地点より上流 } & \multicolumn{2}{|c|}{ 47地点より下流 } & 西関宿～野田 \\
\hline & 水面勾配 & 伝播速度 $(\mathrm{m} / \mathrm{s})$ & 水面勾配 & 伝播速度 $(\mathrm{m} / \mathrm{s})$ & 実測伝播速度 $(\mathrm{m} / \mathrm{s})$ \\
\hline 昭和57年 & $1 / 4500 \sim 1 / 5300$ & $1.2 \sim 1.7$ & $1 / 3200 \sim 1 / 3400$ & $1.6 \sim 2.1$ & 1.90 \\
\hline 平成10年 & $1 / 5300 \sim 1 / 5400$ & $1.2 \sim 1.8$ & $1 / 2300 \sim 1 / 2900$ & $1.8 \sim 2.1$ & 1.42 \\
\hline
\end{tabular}

基準点断面については実測水位から，基準点以外の 断面については福岡らによる ${ }^{5)}$ 計算水位を, $I_{e}$ には, 実測水面形にほぼ一致する計算水面形の水面勾配を 用いている. 产の理由として, 水面形には縦横断的 な断面形状の変化や樹木群など洪水流に影響する全 ての情報が反映されており2）6，水面勾配を用いる ことで光れらの影響を考慮に入れた解析が可能とな ると考えたためである .

表-5,6 は利根川，江戶川における平均的な水面 勾配と式(2)を用いて算出した洪水流の伝播速度の 理論值及び昭和 57 年, 平成 10 年のピーク水位の伝 播から求めた実測伝播速度を示す．理論値について は利根川については分派点で, 江戶川では水面形の 変化点である $47 \mathrm{~km}$ 地点で分けて示した . 伝播速度 に幅を持たせて示したのは，樹木か繁茂している区 間では水面勾配が樹木群の繁茂状況によって変化し， 伝播速度に差が見られるためである . 実測値を見て 分かるように, 平成 10 年洪水は断面形状の変化や 河道内に繁茂した樹木群の影響を受けることで，昭 和 57 年洪水よりも洪水流の伝播に遅れが生じてい る . 実測の伝播速度と比較すると，利根川，江戶川 の各区間ともに計算値との間に差が見られる.計算 では, 断面形状の変化は考慮できているものの, 蛇 行や樹木群の影響については水面勾配を用いること で間接的に考慮している。このため, 河道内に樹木 が少ない昭和 57 年洪水については平成 10 年洪水よ りも比較的対応が良い結果となっている。

本研究は, 洪水流の伝播機構を単純化し, 伝播速 度を理論的に求めたものである.実測の伝播速度を より適切に説明するには, 水面形の時間変化に着目 した著者らが行った非定常平面二次元解析 ${ }^{2 ） 5 ） 6) ~}$ を用いればよいであろう．ここで提示した理論は， 洪水の伝播機構を物理的に説明する上でも，また河 道改修断面を治水面, 環境面から検討する上でも重
要な意味を持つと考えている .これらの点について は , 今後さらに検討する予定である .

\section{6 . 結論}

本研究で得られた主な知見を以下に示す。

1) 複断面形状を有する河道の洪水流の伝播速度 を洪水波形が一定で伝わるという仮定を用い て理論的に導いた. . 理論式は実験水路で行われ た洪水流実験結果を比較的良く説明できるこ とを示した。

2) 洪水流の伝播速度に与える, 蛇行度, 低水路幅, 横断面形状の影響を検討した。さらに，理論式 に基づいて, 横断面形状を変化させた場合の洪 水伝播速度一断面平均流速比変化を調べた。

3) 利根川, 江戶川の代表的な洪水流に理論式を適 用し，洪水流の伝播速度を算出し，実測による 伝播速度と比較した。

\section{参考文献}

1) 水理公式集(平成 11 年度版), 土木学会, 1999.

2) 福岡捷二: 洪水の水理と河道の設計法, 森北出版, 2005.

3) 福岡捷二, 藤田光一：複断面河道の抵抗予測と河道計 画への応用, 土木学会論文集 No. 411/II-12, pp. 63〜 72, 1989.

4) 福岡捷二, 渡邊明英, 關浩太郎, 栗栖大輔, 時岡利和: 河 道における洪水流の貯留機能と光の評価, 土木学会論 文集 No. 740/II- 64, pp31- 44, 2003.

5) 福岡捷二, 渡邊明英, 田端幸輔, 風間聡, 牛腸宏 : 利根 川・江戶川分派点を含む区間における流量ハイドログ ラフと粗度係数・樹木群透過係数の評価, 水工学論文 集, 第 50 巻, pp. 1165-1170, 2006.

6) 福岡捷二:洪水流の水面形観測の意義と水面形に基づ く河川の維持管理技術, 河川技術論文集, 第 12 巻, pp. 1- 6, 2006.

(2006. 9. 30 受付) 